Volume. 2 Nomor. 2

Periode: Juli - Desember 2018; hal. 82-91

p-ISSN : 2580-1112; e-ISSN : 2655-6669

Copyrighr@2018

Penulis memiliki hak cipta atas artikel ini

Jurnal Ilmiah Keperawatan Orthopedi (JIKO)

journal homepage:

https://ejournal.akperfatmawati.ac.id

\title{
Pengaruh Kelompok Swabantu (Self Help Group) Terhadap Harga Diri Penderita Kusta Di Wilayah Kerja Puskesmas Cibuaya Karawang Jawa Barat Tahun 2017
}

\author{
Aisyiah $^{1}$, Tommy J Wowor ${ }^{2}$, Dwi Novi Apriliani ${ }^{3}$ \\ Fakultas Ilmu Kesehatan Universitas Nasional, Jakarta
}

\begin{abstract}
Abstrak
Kejadian kusta di Indonesia hingga saat ini masih tergolong tinggi dengan adanya peningkatan jumlah klien kusta beberapa tahun terakhir. Jawa Barat sebagai peringkat kedua sejumlah 2.222 orang sebagai daerah dengan jumlah kasus terbanyak. Gangguan harga diri pada klien kusta yang ditunjukkan dengan sikap malu, kurang percaya diri, dan perasaan tidak berharga yang didukung dengan stigma masyarakat dan diskriminasi. Di dalam Self Help Group, kelompok bantuan timbal balik dapat saling mendukung dan mengurangi atau menghilangkan masalah dan konsekuensi pribadi dan sosial. Penelitian ini bertujuan untuk mengetahui pengaruh kelompok swabantu (self help group) untuk meningkatkan harga diri penderita kusta pada kelompok kasus dan kelompok kontrol. Desain Penelitian quasi-experiment ini menggunakan rancangan two group, pretest posttest design. Sampel dalam penelitian ini berjumlah 45 pasien kusta. Instrumen penelitian terdiri dari kuesioner tentang harga diri yaitu CSEI. Data dianalisis menggunakan Uji T yaitu paired t test untuk mengetahui perbedaan skor harga diri dalam satu kelompok dan Independent t-test untuk mengetahui perbedaan skor harga diri antar kelompok. Hasil Penelitian menunjukkan bahwa ada perbedaan yang signifikan pada skor harga diri sebelum dan sesudah diberikan intervensi self help group pada kelompok kasus dan kelompok kontrol $(p<0,05)$, serta tidak terdapat perngaruh yang signifikan pada skor harga diri antara kelompok kasus dan kelompk kontrol setelah diberikan intervensi self help group ( $p>0,05$ ). Kelompok Swabantu (self help group) mampu meningkatkan harga diri pada penderita kusta. Self help group merupakan salah satu intervensi yang tepat digunakan dalam meningkatkan harga diri pasien kusta.
\end{abstract}

Kata kunci: Kusta, Harga Diri, Kelompok Swabantu (Self Help Group)

\begin{abstract}
The incidence of leprosy in Indonesia is still relatively high today with an increase in the number of leprosy clients in the past few years. West Java is ranked second with 2,222 people as the region with the highest number of cases. Disturbance of self-esteem in leprosy clients indicated by an attitude of shame, lack of confidence, and feelings of worthlessness supported by community stigma and discrimination. Within the Self Help Group, reciprocal assistance groups can support and reduce or eliminate personal and
\end{abstract}

1,2,3 e-mail: chy_a16@yahoo.co.id 
social problems and consequences. This study aims to determine the effect of self-help groups to increase the self-esteem of lepers in the case and control groups. The design of this quasi-experimental study uses a two group design, pretest post-test design. The sample in this study amounted to 45 leprosy patients. The research instrument consisted of a self-esteem questionnaire, CSEI. Data were analyzed using the T test, which was paired $t$ test to determine differences in self-esteem scores in one group and Independent t-test to determine differences in self-esteem scores between groups. The results showed that there were significant differences in self-esteem scores before and after self-help group intervention in the case group and the control group ( $p<0.05)$, and there was no significant effect on self-esteem scores between cases and control groups. after being given a self help group intervention ( $p>0.05$ ). Self-help groups (self help group) are able to increase self-esteem in lepers. Self help group is one of the appropriate interventions used to improve the self-esteem of leprosy patients.

Keywords: Leprosy, Self-Esteem, Self-Help Group (Self Help Group)

\section{Pendahuluan}

Kusta adalah suatu penyakit akibat infeksi bakteri Mycobacterium Leprae dan terutama menyerang kulit, membran mukosa (misalnya hidung), saraf perifer, mata, dan testis. Infeksi dari kusta tergantung dari sistem kekebalan seseorang. Penyakit kusta dapat disembuhkan, namun bila tidak diobati akan dapat menyebabkan cacat yang permanen (Ngan, 2011).

Sampai saat ini, program eliminasi kusta terus diperbaharui. WHO mengembangkan berbagai macam strategi untuk mencapai tujuan program eliminasi kusta.

Program terbaru dari WHO yaitu "Strategi Enchaned Global Strategy for Futher Reducing The Disease Burden to Leprosy 2011-2015” (WHO, 2009). Program eliminasi kusta ditempuh melalui kebijakan deteksi dini kasus kusta dan pengobatan dengan terapi obat kombinasi dari dapsone, rifampicin, dan clofazimine (Multi Drug Theraphy/MDT) secara gratis, bekerjasama dengan lintas sektoral, dan lain-lain. Salah satu sasaran program eliminasi ini adalah meningkatkan kesadaran dan pengetahuan masyarakat terhadap penyakit kusta (WHO, 2009).

Pengetahuan masyarakat yang rendah dan mitos terkait penyakit kusta menyebabkan timbulnya sikap masyarakat yang cenderung negatif terhadap penderita kusta. Stigma atau label yang diberikan masyarakat terhadap penderita kusta antara lain penyakit kusta sering dianggap sebagai penyakit keturunan, hukuman, atau kutukan dari Tuhan, sangat menular, dan tidak dapat diobati.

Penelitian yang dilakukan dibeberapa negara menyatakan pengetahuan masyarakat terkait penyakit kusta masih rendah dan kesalahpahaman terkait penyebab, penularan, dan pengobatannya (Shetty et al., 1985 dalam Padmini, 2003).

Menurut Weekly Epidemiological Record bahwa di Indonesia ditemukan 21.538 kasus kusta, sedangkan didunia kasus yang dilaporkan 312.036, dan jumlah kasus baru pada pertengahan tahun 2008 dilaporkan dari 121 negara sebanyak 249.007 kasus (Weekly Epidemiological Record, 2009). Tahun 2006, The International Federations of Anti Leprosy Associations (ILEP) dan WHO mengeluarkan strategi global untuk menurunkan beban penyakit dan kesinambungan program pemberantasan penyakit kusta (tahun 2006-2010).

Sejak pertengahan tahun 2006 strategi tersebut dipakai dalam kebijakan pemberantasan penyakit kusta di Indonesia. Menurut WHO, diperkirakan jumlah penderita kusta baru di dunia 
pada tahun 2005 (di luar regional Eropa) adalah sekitar 296.499 orang. Dari jumlah tersebut terbanyak terdapat di regional Asia Tenggara : 201.635 kasus, diikuti regional Afrika : 42.814 kasus, regional Amerika : 47.780 kasus dan sisanya berada pada regional lain di dunia. Awal tahun 2006, di dunia terdapat 219.826 kasus dengan perincian regional Asia Tenggara 133.422 kasus, regional Afrika : 40.830 kasus dan regional Amerika 32.904 kasus, sedangkan sisanya berada di regional lainnya.

Strategi WHO global merupakan indikator eliminasi kusta yaitu angka penemuan penderita (New Case Detection Rate/NCDR) yang menggunakan indicator utama sebelumnya yaitu angka penemuan penderita terdaftar (prevalensi rate $<1 / 10.000$ penduduk). (Ditjen PP-PL, Kemenkes RI, 2008). Pada tahun 2000 NCDR menampilkan tren yang meningkat.

Namun sejak tahun 2005, NCDR turun dari 0,9 menjadi 0,83 pada tahun 2006 kembali turun, pada tahun 2007 menjadi 0,78 per 10.000 penduduk. Jumlah penderita baru yang ditemukan sepanjang tahun 2007 sebesar 17.726 dengan rincian Pausi Basiler (PB) sebanyak 3.643 penderita dan Multi Basiler (MB) sebanyak 14.083 penderita. Sedangkan prevalensi kusta menunjukan kecenderungan peningkatan.

Pada tahun 2000 prevalensi sebesar 0,86 per 10.000 penduduk menjadi 1,05 per 10.000 penduduk pada tahun 2007. Berdasarkan distribusi per provinsi, prevalensi kusta tertinggi terdapat di provinsi Papua Barat sebesar 9,69 diikuti oleh Maluku Utara sebesar 6,66 dan Papua sebesar 4,42 per 10.000 penduduk.

Meskipun Indonesia telah mencapai eliminasi kusta pada tahun 2000, namun hingga kini penemuan kasus kusta masih dijumpai di beberapa daerah. Berdasarkan kondisi tersebut Kementerian Kesehatan RI menargetkan agar seluruh provinsi dapat mencapai status eliminasi kusta pada tahun 2019.

Menurut Kementerian Kesehatan RI (2016) saat ini, sejumlah 20 dari 34 Provinsi yang sudah berhasil mengeliminasi kusta. Tahun 2016 target untuk eliminasi kusta adalah provinsi Sulawesi Tengah dan Aceh Tahun 2017, target eliminasi kusta di Sulawesi Tenggara, Jawa Timur, dan Sulawesi Selatan. Tahun 2018, target eliminasi kusta di Sulawesi Barat, Sulawesi Utara, dan Gorontalo.

Strategi yang digunakan untuk mengurangi kejadian kusta di Indonesia menurut Kementerian Kesehatan RI (2016) adalah penemuan dan pengobatan dini secara teratur, serta promosi kesehatan tentang pencegahan penularan dan pencegahan kecacatan.

Kejadian kusta di Indonesia hingga saat ini masih tergolong tinggi dengan adanya peningkatan jumlah klien kusta beberapa tahun terakhir.

Menurut Kementerian Kesehatan RI (2015) kejadian kusta di Indonesia pada tahun 2012 mencapai 16.123 sedangkan pada tahun 2013 mencapai 16.856 orang. Sementara itu pada tahun 2014 jumlah klien mencapai 17.025 orang (Kemenkes RI, 2015).

Jumlah tersebut tersebar di berbagai daerah dengan jumlah kasus terbanyak kusta berada di daerah Jawa Timur pada peringkat pertama mencapai 4.116 orang, diikuti Jawa Barat sebagai peringkat kedua sejumlah 2.222 orang dan Jawa tengah sebagai peringkat ketiga sejumlah 1.829 orang (Kemenkes RI, 2015).

Dari data Dinas Kesehatan Provinsi Jawa Barat jumlah penderita penyakit kusta baru di Jawa Barat dari Januari-September 2011 tercacat 1.499 orang, sementara itu yang sedang berobat hingga September 2011 tercatat 2.107 orang.

Penyakit kusta ini bukan penyakit turunan, namun banyak menyerang beberapa orang dalam satu keluarga akibat kontak yang erat. Lima daerah 
yang termasuk banyak ditemukan penderita kusta baru adalah Kabupaten Cirebon sebanyak 237 orang, Kabupaten Indramayu 211 orang, Kabupaten Bekasi 191 orang, Kota Bekasi 145 orang dan Kabupaten Subang 126 orang. (Dinkes Provinsi Jawa Barat, 2012).

Sementara itu, jumlah penderita kusta di provinsi Karawang Jawa Barat pada tahun 2013 adalah berjumlah 384 orang yang terbagi dalam beberapa desa di Karawang (Dinas Kesehatan Karawang, 2013).

Menurut Potter dan Perry (2005) perubahan yang dialami individu akibat penyakit yang menyebabkan terganggunya kemampuan dalam melakukan aktivitas yang menunjang perasaan berharga dan berguna maka akan mempngaruhi harga diri. Semakin kronis suatu penyakit maka semakin besar pula pengaruhnya bagi harga diri seseorang.

Harga diri rendah diekspresikan dalam bentuk kecemasan, ketakutan, ketidakberdayaan, keputuasaan, dan tidak berharga (Stuart, 2013). Beberapa dampak psikologis yang ditimbulkan menunjukkan klien kusta mengalami gangguan harga diri rendah.

Gangguan harga diri pada klien kusta merupakan manifestasi dari beberapa stressor. Adanya kecacatan pada klien kusta merupakan stressor yang dapat mengganggu konsep diri terutama harga diri. Setiap perubahan yang terjadi dalam kesehatan merupakan salah satu stressor yang mempengaruhi konsep diri (Potter \& Perry, 2005).

Kecacatan pada klien kusta dianggap hal yang menyeramkan bagi individu maupun masyarakat disekitarnya. Kerusakan fisik yang nyata berupa kecacatan dalam berbagai bentuk yang sangat mengerikan merupakan salah satu faktor penyebab sulitnya masyarakat disekitar dalam menerima keberadaan penderita kusta dan keluarganya (Fajar, 2010).

Akhirnya hal ini menimbulkan diskriminasi pada klien kusta. Stigma dan diskriminasi merupakan konsekuensi yang harus diterima oleh klien yang menderita penyakit yang termasuk dalam Neglected Tropical Disease seperti kusta (CDC, 2011).

Self Help Group atau sering disebut juga kelompok yang saling menolong, saling membantu, atau kelompok dukungan didefinisikan sebagai suatu kelompok yang menyediakan dukungan bagi setiap anggota kelompok.

Anggota kelompok ini berpegangan pada pandangan bahwa orang-orang yang mengalami masalah dapat saling membantu satu sama lain dengan empati yang lebih besar dan lebih membuka diri (Ahmadi, 2007 cit Keliat, 2008).

Self help group sangat mungkin diadakan di Puskesmas. Berdasarkan keterangan dari petugas kesehatan, pasien kusta akan kontrol minimal 1 bulan sekali jika obatnya habis dan kurang dari 1 bulan jika terjadi reaksi berulang.

Kesempatan ini bisa digunakan untuk mengadakan self help group dalam mendukung pasien menyelesaikan masalah yang dihadapi baik sudah dirumah atau masalah lain. Selain itu tempat resmi (seperti Rumah Sakit atau Puskesmas) membuat pasien kusta tidak merasa malu karena diketahui oleh tetangga sekitar, karena jika diadakan di salah satu rumah warga, akan diketahui bahwa ia juga terkena kusta (Kemenkes, 2006).

Terkait hal dengan masih tingginya angka kejadian kusta yang berada diwilayah kerja Puskesmas Cibuaya serta kurangnya pengetahuan penderita dan masyarakat tentang penyakit kusta maka penulis tertarik untuk melakukan penelitian dengan judul Pengaruh Kelompok Swabantu (Self Help Group) Terhadap Harga Diri Penderita Kusta di Wilayah Kerja Puskesmas Cibuaya Karawang Jawa Barat Tahun 2017. 
Tujuan Penelitian ini adalah untuk mengetahui pengaruh kelompok swabantu (Self Help Group) terhadap harga diri penderita kusta di wilayah kerja Puskesmas Cibuaya Karawang Jawa Barat.

\section{Metodologi Penelitian}

Desain penelitian yang digunakan adalah quasi eksperimen, dengan Two Group, Pretest Post-test Design, yaitu kelompok eksperimen dan kontrol sebelum dilakukan perlakuan observasi untuk menjamin bahwa kedua kelompok tersebut sebelum mendapat

Tabel 1. Gambaran sebaran nilai rata-rata harga diri rendah pada penderita kusta sebelum dan sesudah dilakukan intervensi pada kelompok kasus

\begin{tabular}{llllll}
\hline Harga Diri Rendah & Mean & Median & SD & Min-maks & $P$ value \\
\hline Pre test & 31,63 & 31,00 & 5,541 & $23-47$ & 0,000 \\
Post test & 45,67 & 46,00 & 1,074 & $44-48$ & \\
\hline
\end{tabular}

Berdasarkan tabel 1 diketahui nilai rata-rata harga diri rendah pada kelompok kasus sebelum intervensi adalah 31,63, dengan nilai skor terendah adalah 23 dan nilai skor tertinggi adalah 47. Nilai rata-rata harga diri rendah pada perlakuan sama dan jika berbeda itu dapat dikendalikan.

Penelitian ini menggambarkan perbandingan antara 2 kelompok, yaitu kelompok eksperimen dan kelompok kontrol. Kelompok eksperimen pada penelitian ini dilakukan pendidikan kesehatan dengan menggunakan pendekatan Self Help Group sedangkan pada kelompok kontrol diberi pendidikan kesehatan dengan pembagian leaflet.

\section{Hasil Penelitian}

kelompok kasus setelah diberikan intervensi menggunakan flipchart adalah 45,67, sedangkan nilai skor terendah adalah 44 dan nilai skor tertinggi adalah 48.

Tabel 2 Gambaran sebaran nilai rata-rata harga diri renda pada penderita kusta sebelum dan sesudah diberikan intervensi pada kelompok kontrol

\begin{tabular}{llllll}
\hline Harga Diri Rendah & Mean & Median & SD & Min-maks & $P$ value \\
\hline Pre test & 31,22 & 31,00 & 4,660 & $25-46$ & 0,000 \\
Post test & 43,83 & 45,00 & 5,437 & $29-50$ & \\
\hline
\end{tabular}

Berdasarkan tabel 2 diketahui nilai rata-rata harga diri rendah pada kelompok kontrol sebelum intervensi adalah 31,22, dengan nilai skor terendah adalah 25 dan nilai skor tertinggi adalah 46. Nilai rata-rata harga diri rendah pada kelompok kasus setelah diberikan intervensi menggunakan leaflet selama 1 kali pertemuan adalah 43,83, sedangkan nilai skor terendah adalah 29 dan nilai skor tertinggi adalah 50 .

Tabel 3 Analisis pengaruh kelompok swabantu (self help group) terhadap harga diri penderita kusta di Puskesmas Cibuaya Karawang Jawa Barat

\begin{tabular}{lllll}
\hline Rata-rata harga diri sesudah intervensi & Median & SD & Min-maks & P value \\
\hline Harga diri kelompok kasus & 46,00 & 0,27 & $44-48$ & 0,175 \\
Harga diri kelompok kontrol & 45,00 & 1,281 & $29-50$ & \\
\hline
\end{tabular}

Berdasarkan tabel 3 diketahui nilai tengah harga diri rendah pada kelompok kasus sesudah diberikan intervensi adalah 46,00, dengan harga diri terendah adalah 44 dan harga diri tertinggi adalah 48. Dan nilai tengah harga diri rendah pada kelompok kontrol sesudah diberikan intervensi adalah 45,00, harga diri terendah adalah 29 dan harga diri rendah tertinggi adalah 50 . 
Hasil analisa bivariat dengan menggunakan uji independent $\mathrm{t}$ test didapatkan nilai $p$ value sebesar 0,175 , berarti $p$ value $>\alpha(\alpha=0,05)$, sehingga Ho diterima dan $\mathrm{H} 0$ diterima maka tidak terdapat pengaruh kelompok swabantu terhadap harga diri penderita kusta di Puskesmas Cibuaya Karawang Jawa Barat Tahun 2017.

\section{Pembahasan}

Hasil penelitian table 1 menunjukkan bahwa responden yang belum diberikan intervensi self help group memiliki nilai rata-rata 31,63 , sedangkan responden yang sudah diberikan intervensi self help group mempunyai nilai rata-rata 45,67.

Hal ini menunjukkan adanya peningkatan nilai rata-rata dengan $p$ value 0,000 yang menunjukkan adanya perbedaan yang signifikan antara sebelum diberikan intervensi dengan sesudah diberikan intervensi dan adanya peningkatan harga diri responden pada kelompok kasus.

Hasil penelitian ini berkaitan dengan hasil penelitian yang dilakukan oleh Visram (2012) tentang peran self help group dalam meningkatkan kesehatan pada orang dengan kanker, didapatkan bahwa dengan ikut dalam kelompok, mereka telah dipandang secara holistik, bukan hanya fisik saja. Mereka juga mengungkapkan ada hubungan emosional disana, pertemanan, berbagi pengalaman yang dapat meningkatkan gairah hidup mereka.

Selain itu mereka juga mengungkapkan dapat ikut berpartisipasi aktif dalam kegiatan kelompok dan anggota yang lain menganggap mereka sebagai seseorang yang mempunyai tujuan hidup.

Pada intervensi kelompok kasus dibentuk kelompok swabantu (self help group) dengan bantuan metode media flipchart. Self help group dilakukan pertemuan 1 kali dalam 1 minggu dan diadakan selama 3 minggu. Setiap pertemuan dlaksanakan selama 45 menit -1 jam.

Materi yang diberikan adalah pengenalan lebih dalam tentang penyakit kusta, cara penularan kusta terhadap orang lain, pengobatan kusta dan cara mencegah agar tidak terjadi kecacatan dan apabila sudah terjadi cacat diberikan informasi tentang cara merawat diri untuk yang sudah mengalami kecacatan.

Dalam pemberian intervensi ini, peneliti dibantu oleh pemegang program kusta dari Puskesmas Cibuaya. Di dalam pelaksanaan intervensi, dilakukan tanya jawab antara peneliti dan pasien. Pasien juga diberikan kesempatan untuk menceritakan pengalamannya setelah mengetahui bahwa pasien terkena kusta serta memecahkan masalah bersamasama.

Hasil penelitian pada table 2 menunjukkan bahwa responden yang belum diberikan leaflet memiliki nilai rata-rata 31, 22, sedangkan responden yang hanya diberikan leaflet mempunyai nilai rata-rata 43,83 .

Hal ini menunjukkan adanya peningkatan nilai rata-rata dengan $p$ value 0,000 yang menunjukkan adanya perbedaan yang signifikan antara sebelum diberikan leaflet dengan sesudah diberikan leaflet dan adanya peningkatan harga diri responden pada kelompok kontrol.

Hasil penelitian ini tidak sesuai dengan penelitian yang dilakukan Sentika (2014) tentang pengaruh self help group (SHG) terhadap perubahan dan ketergantungan merokok pada siswa disalah satu sma di Yogyakarta. Metode penelitian yang dipakai adalah quasy eskperiment.

Hasil dari penelitian ini mengungkapkan bahwa terdapat pengaruh SHG terhadap perubahanperubahan perilaku dengan $\mathrm{p}=0,000$ $(<0,05)$. Namun SHG tidak berpengaruh terhadap ketergantungan merokok siswa dengan $\mathrm{p}=0,427 \quad(>0,05)$, terdapat perbedaan perilaku antara kelompok intervensi dan kontrol dengan $\mathrm{p}=0,000$ 
$(>0,05)$, tidak terdapat perbedaan pada kelompok intervensi dan control ketergantungan merokok siswa dengan $\mathrm{p}$ $=0,11(>0,05)$.

Pada kelompok kontrol hanya diberikan leaflet 1 kali pertemuan saja dan tidak ada intervensi lain, yang berfungsi sebagai media informasi yang dapat menjelaskan secara lebih singkat mengenai kusta, penyebab kusta, cara penularan, cara perawatan diri untuk pasien kusta.

Sedangkan pada tabel 3 didapatkan bahwa pada kelompok kasus tidak terdapat perbedaan tingkat harga diri dilakukan intervensi yaitu pembentukan kelompok swabantu (self help group) dengan bantuan menggunakan media flipchart.

Tidak adanya perbedaan tingkat harga diri sebelum dan sesudah pendidikan kesehatan dikarenakan banyak variabel lain yang tidak diteliti seperti, pengetahuan, pendidikan, umur serta dukungan keluarga yang menjadikan intervensi kelompok swabantu ini tidak menunjukkan adanya perbedaan tingkat harga diri pada penderita kusta.

Sedangkan penelitian pada kelompok kontrol yang hanya diberikam leaflet menunjukkan bahwa tingkat harga diri responden juga mengalami tidak perbedaan antara sebelum dan sesudah menerima pendidikan kesehatan. Media leaflet merupakan salah satu bentuk media informasi yang mudah dan murah, serta informasi yang terdapat dalam leaflet lebih mudah diterima.

Hal ini dapat terjadi karena leaflet yang diberikan pada saat pendidikan kesehatan dapat dibaca berulang-ulang oleh responden dan dibawa pulang ke rumah. Pengetahuan yang diperoleh dari leaflet ini dapat merubah cara pandang responden tentang penyakit kusta dan bagaimana bersikap terhadap penderita kusta dalam berinteraksi dengan masyarakat.

Suiraoka \& Supariasa (2012) mengatakan bahwa kelebihan media leaflet adalah dapat disimpan lama, sasaran dapat menyesuaikan dan belajar mandiri, pengguna dapat melihat isinya saat santai, jangkauan sasaran lebih luas, dapat membantu media lain, dan isi dapat dicetak kembali.

Tetapi dengan keterbatasan dari penderita kusta, seperti lagofthalamus, infeksi dan kebutaan tidak menjadikan media leaflet akan dibaca dan dipahami secara berulang-ulang karena keterbatasan yang dimilikinya.

Hasil uji statistik diperoleh $p$ value: 0,175 berarti $p$ value $>\alpha(\alpha=$ $0,05)$. Sehingga dapat disimpulkan H0 diterima dan $\mathrm{H}$ ditolak, maka dapat disimpulkan bahwa tidak ada perbedaan yang signifikan antara harga diri sebelum dan sesudah intervensi self help group pada kelompok kasus dan kontrol. Tidak adanya perbedaan ini, dikarenakan terdapat banyak variabel yang tidak diteliti, seperti pengetahuan, pendidikan, jenis kelamin, umur serta dukungan keluarga yang menjadikan tidak terdapat perbedaan tingkat harga diri pada penderita kusta.

Hal ini tidak sesuai dengan penelitian Carter (2007) tentang pengalaman orang tua dalam kelompok self help group pada anak autis mengungkapkan bahwa terdapat pengalaman positif dan negatif saat mengikuti self help group.

Pengalaman positif yang didapat antara lain menambah pengetahuan tentang tindakan yang dilakukan pada anak autis, meningkatkan harga diri, merasa ada harapan, saling mendukung, dan adanya peran saling memberi antar anggota kelompok.

Self help group merupakan salah satu metode yang dapat meningkatkan harga diri pasien kusta. Diharapkan dengan meningkatnya harga diri, akan membuat pasien lebih percaya diri dalam menghadapi masyarakat, namun jika tidak ada kerja sama yang baik antara semua pihak, masyarakat akan terus berfikir negatif tentang kusta dan ini yang akan membuat pasien mengalami 
penurunan harga diri kembali karena persepsi masyarakat yang negatif.

Seperti penelitian Rahcman (2012) tentang persepsi masyarakat terhadap penyakit kusta di Wilayah Kerja Puskesmas Kalumata Kota Ternate menunjukkan bahwa masyarakat mengungkapkan bahwa penyakit kusta merupakan penyakit keturunan dna kutukan, penyebabnya karena lingkungan yang kotor, bakteri dan guna-guna, dan masyarakat masih takut berinteraksi dengan penderita.

Selain itu penelitian Etnawati (2007) tentang persepsi masyarakat terhadap penyakit kusta di Kecamatan Cambai Prabumulih menunjukkan bahwa sebagian masyarakat menganggap kusta sebagai penyakit keturunan, kutukan, hukuman, masyarakat merasa takut dan jijik pada penderita kusta.

Persepsi negatif yang sangat melekat ini akan menimbulkan resistensi di masyarakat. Oleh karena itu, harus dicari solusi atau metode yang tepat untuk menyelesaikannya.

Analisa peneliti menunjukkan bahwa kelompok swabantu (self help group) memberikan dampak yang positif bagi pasien kusta tetapi tidak dibuktikan dengan peningkatan harga diri setelah diberikan intervensi dengan kelompok swabantu (self help group). Karena dengan banyaknya variabel yang tidak diteliti memungkinkan tidak meningkatnya harga diri pada penderita kusta.

\section{Kesimpulan}

Terdapat perbedaan sigfinikan pada kelompok kasus yang diberikan intervensi self help group ditinjau dari hasil pre test dan post test didapatkan nilai $p$ value $(0,000)$ dan perbedaan yang sigfinikan pada kelompok kontrol ditinjau dari hasil pre test dan post test didapatkan nilai $p$ value $(0,000)$.

Selain itu, tidak terdapat pengaruh signifikan pemberian intervensi self help group terhadap harga diri penderita kusta di wilayah kerja
Puskesmas Cibuaya Karawang Jawa Barat Tahun $2017(P$ value $=0,175>\alpha)$.

\section{Saran}

1. Bagi Pasien dan Keluarga

Pasien diharapkan mampu menginterpretasikan apa yang sidah didapatkan selama intervensi self help group. Pasien dapat lebih aktif untuk menanyakan atau berkonsultasi ke petugas kesehatan terkait penyakit ataupun masalah yang ditimbulkan akibat kusta. Keluarga diharapkan mampu menjadi support system yang baik bagi pasien, bukan hanya dari segi material, namun juga memberikan dukungan psikologis pada pasien.

2. Bagi Puskesmas

Puskesmas dapat membuat program terkait dukungan keluarga, pihak puskesmas juga dapat menetapkan apa saja yang dilakukan pada keluarga, misalnya dengan diberikan penyuluhan kesehatan dan meyakinkan keluarga bahwa dukungan keluarga sangat penting dalam proes penyembuhan pasien.

3. Penelitian lebih lanjut

Perlu dilakukan penelitian yang bersifat kualitatif yang dapat menggali labih jauh aspek-aspek yang terkait penyakit kusta, antara lain persepsi tentang kusta pada penderita, keluarga dan masyarakat. Selain juga dapat dilakukan penelitian terkait tentang strategi koping yang dilakukan dalam menghadapi penyakit kusta.

\section{Daftar Pustaka}

[1] Aziz, dkk. 2012, Pengetahuan Sikap Dan Perilaku Kiai Terkait Kusta. Studi Kasus di Kabupaten Sampang. Jakarta: Komisi Nasiona Hak Asasi Manusia.

[2] Fajar, N.A. 2010, Dampak Psikososial Penderita Kusta dalam Proses Penyembuhan, Jurnal Pembangunan Manusia, 10 (1): 2-5. 
[3] Friedman, M.M. 2010, Buku Ajar Keperawatan Keluarga, Riset, Teori dan Parktik, Jakarta: EGC.

[4] Harjo, 2002, Faktor-Faktor yang Berhubungan dengan Ketidakteraturan Berobat Penderita Kusta di Kabupaten Majalengka tahun 1998-2000, Tesis, Univeritas Indonesia.

[5] Hasnani, 2003, Kejadian Cacat Tingkat 2 Pada Penderita Kusta Dan Faktor-Faktor Yang Mempengaruhi di Provinsi Nanggroe Aceh Darussalam tahun 2002, Tesis, Universitas Indonesia.

[6] Hiswani, 2001, Kusta Salah Satu Penyakit Menular yang Masih Dijumpai di Indonesia, Fakultas Kedokteran, Universitas Indonesia.

[7] Infopublik.org, Kementeriian Komunikasi dan Informatika, Angka Kecacatan Tingkat II Akibat Kusta 10,37\% diakses 4 Oktober 2017.

[8] Jemeli, V. 2010, WHO: 17Penyakit Tropis Terabaikan, Diakses dari http://health.kompas.com/index.php/ read/2010/10/15/04191358/WHO.17 .Penyakit.Tropis.Terabaikan-8 tanggal 26 September 2017.

[9] Kementerian Kesehatan RI. 2012, Pedoman Nasional Pengendalian Penyakit Kusta, Jakarta: Direktorat Jenderal Pengendalian Penyakit dan Penyehatan Lingkungan Kementerian Kesehatan Republik Indonesia.

[10] Kementerian Kesehatan RI. 2014, Kusta, Penyakit Menular yang Sulit Menular, www. depkes. go. id, [serial online]. http://www.depkes.go.id/article/print 2014420003/ kusta-penyakitmenular-yang-sulit-menular.html. [26 September 2017]

[11] Kemenkes RI, 2016, Kusta, Infodatin dan Informasi Kesehatan Kementerian RI, www.datakemenkes.co.id diakses 01 Oktober 2017.

[12] Kurnianto, Joko, 2002, FaktorFaktor Yang Berhubungan Dengan
Kecacatan Penderita Kusta di Kabupaten Tegal, Tesis, Univeritas Diponegoro.

[13] Kurniawan, Bagus. 2011, Penderita Lepra di Indonesia Terbesar ke-3 di Dunia, [serial online], http://us.health.detik.com/read/2011 104/07/171659/1611158/763/penderi ta-lepra-di-indonesia-terbesar-ke3di-dunia?ld001103763, Diakses 20 September 2017.

[14] Marhaento, F, Faktor-Faktor Penentu Ketidakteraturan Berobat Penderita Kusta di Yograkarta Tahun 2002, Sains Kesehatan 17 (4) Oktober 2004.

[15] Missouri Departement of Health and Senior Services, Section for Communicable Disease Prevention, Hansen's Disease (Leprosy).

[16] Noto, S.\& Schreuder, P.A.M. 2010, Clinical Leprosy. Genoa.

[17] Panatalone, M. 2013, Alcoholrelated problems and self-helpgroups: The situasional construction of self-image. Italian Sociological Review, 3(2), 71-83. Retrieved from http://search.proquest.com/docview/ 1443261095 ? accountid=17242.

[18] Panigoro, S. 2007, Beberapa Faktor Yang Mempengaruhi Keteraturan Berobat Kusta Di Provinsi Gorontalo, Tesis, Program Pascasarjana Minat Utama Field Epidemilogi Training Program (FETP) Program Studi Ilmu Kesehatan Masyarakat Jurusan Ilmu-ilmu Kesehatan UGM, Diakses dari http://puspasca.ugm.ac.id/files/abst, Tanggal 17 September 2017.

[19] Prawoto, P. 2008, Faktor-faktor Risiko yang Berpengaruh terhadap terjadinya Reaksi Kusta (Studi di wilayah kerja Puskesmas Kabupaten Brebes), Jurnal Epidemiologi.

[20] Penyakitmenular,info, Dirjen P2\&PL, Kemenkes RI, Pemberantasan Penyakit Kutsa, diakses 3 Oktober 2017. 
[21] Permata.co.id, PermataPerhimpunan Mandiri Kusta Indonesia, Sejarah Kusta, diakses 30 September 2017.

[22] Prastiwi, 2010, Faktor-Faktor Yang Berhubungan Dengan Cacat Tingkat 2 Pada Penderita Kusta Di Rumah Sakit Kediri Jawa Timur, Skripsi, Universitas Airlangga.

[23] Prawoto, 2008, Faktor-Faktor Yang Berpengaruh Terhadap Terjadinya Reaksi Kusta (Studi di Wilayah Kerja Puskesmas Kabupaten Brebes), Tesis, Universitas Diponegoro.

[24] Pitakasari, A. R. 2012, Jangan Diskriminasi Penderita Kusta, Artikel, Republika. co.id [serial online],

http//:www.republika.co.id/berita/na sional/umum/1202/27/m01ri5-

jangan diskriminasi-penderita-kusta. [27 September 2017]

[25] Rachman, H.W.A. 2010, Pola Pencarian Penderita Penyakit Kusta di Kotamadya Makassar.

[26] Rahayuningsih, E. 2012, Analisa Kualitas Hidup Penderita Kusta di Puskesmas Kedaung Wetan Kota Tangerang Tahun 2012, Tesis, Depok, Program Pascasarjana Universitas Indonesia.

[27] Sjamsoe-Daili, dkk. 2003, Penyakit Kusta. Jakarta. Fakultas Kedokteran Universitas Indonesia.

[28] Slamet, E.S., Sukandar, H., dan Gondodiputro, S. Tanpa Tahun, Faktor-faktor yang Mempengaruhi Quality Of Life Orang Yang Pernah menderita Kusta di Kabupaten Cirebon. Artikel Penelitian, Bandung, Lembaga Penelitian Universitas Padjajaran.

[29] Susanto, N. 2006, Faktor-faktor yang Berhubungan dengan Tingkat Kecacatan Penderita Kusta [serial online], Tesis, Yogyakarta, Program Pascasarjana Universitas Gajah Mada.

[30] Susanto, T. 2010, Pengalaman Klien Kusta Menjalani, Perawatan Kusta di Wilayah Kerja Puskesmas Jenggawah Kabupaten Jember Jawa Timur: Studi Fenomenologi, Tesis, Depok, UI.

[31] Soedarjatmi, S. 2008, Faktor-faktor yang Melatarbelakangi Persepsi Penderita Kusta terhadap Stigma Penyakit Kusta (Studi Kualitatif), Doctoral dissertation, Program Pasca Sarjana Universitas Diponegoro.

[32] Tauchid, I. 2006, Faktor-faktor yang Berkaitan dengan Tingkat Kecacatan Kusta di Kabupaten Brerebs Tahun 2005, Tesis, Universitas Diponegoro.

[33] Visram, N., Roberts, A., \& Seebohm, P. 2012, The role of selfhelp groups in pro,otimg well-being: Experiences from a cancer group, Mental Health and Social Inclusion, 16(3), 139-146, doi:http://dx.doi.org/10.1108/20428 4012112255428

[34] WHO, 2010, World Health Statictics 2010.

[35] WHO, 2011, Weekly Epidemiological Record, No. 36, 2 September 2011.

[36] Yudied, AM, dkk, Kajian Pengendalian Potensial Faktor Risiko Penularan Penyakit Kusta dan Intervensinya di Puskesmas Pragaan Kabupaten Sumenep Tahun 2007, Buletin Human Media Volume 03 Nomor 03 Septemer 2008.

[37] Zulkifli, 2003, Penyakit Kusta dan Masalah yang Ditimbulkannya, Fakultas Kesehatan Masyarakat, Universitas Sumatera Utara. 